\title{
Soilless system on peat reduce trace metals in urban-grown food: unexpected evidence for a soil origin of plant contamination
}

\author{
Giuseppina Pennisi $^{1} \cdot$ Francesco Orsini $^{1}$ (D) Daniela Gasperi $^{1} \cdot$ Silvia Mancarella $^{1}$. \\ Rabab Sanoubar ${ }^{1}$ - Livia Vittori Antisari ${ }^{1}$ - Gilmo Vianello ${ }^{1}$ - Giorgio Gianquinto ${ }^{1}$
}

Accepted: 3 August 2016/Published online: 23 September 2016

(C) INRA and Springer-Verlag France 2016

\begin{abstract}
Urban horticulture is increasingly popular for social and economic benefits. However, edible urban crops may be contaminated by airborne pollutants, thus leading to serious health risks. Therefore, a better understanding of contamination risks of urban cultivation is needed in order to define safe practices. In particular, whereas it is commonly accepted that the contamination of urban-grown food comes from airborne pollutants, little is known on a possible contamination by soils. Here, we studied trace metal risk in horticultural crops grown in an experimental urban allotment garden in Bologna, Italy. Seven experiments were conducted between June and November 2015 on tomato, sweet basil, onion, lettuce, kale, bulb fennel and radish. Treatments included two growing systems, soil and soilless, and two fertilization managements, mineral and organic. Trace metal concentrations were measured in soils, substrates and edible plant tissues. We identified preferentially translocated metals by partitioning analysis of tomato, sweet basil and kale. Results showed that crops grown in a soilless system have a lower metal content of $-70 \%$ for $\mathrm{Cr},-61 \%$ for $\mathrm{Cu},-45 \%$ for $\mathrm{Cd}$ and $-81 \%$ for $\mathrm{Ni}$, compared with those grown in soil. This finding demonstrates that the major contamination risk in an urban area is unexpectedly related to soil pollution.
\end{abstract}

Keywords Urban gardening $\cdot$ Soilless cultivation $\cdot$ Food safety $\cdot$ Heavy metals $\cdot$ Plant nutrition

Francesco Orsini

f.orsini@unibo.it

1 Research Centre in Urban Environment for Agriculture and Biodiversity, Department of Agricultural Sciences, University of Bologna, Bologna, Italy

\section{Introduction}

Urban agriculture activities are commonly found in Europe and all over the world. These include the production of crop and livestock goods not only within cities and towns (Zezza and Tasciotti 2010) but also peri-urban agricultural areas which may provide product to the local population, such as vegetables, medicinal plants, fruit trees, ornamental plants, milk, meat and wool (Lin et al. 2015). Urban allotment gardens are one element of the urban green infrastructure that is becoming increasingly important in urban landscape planning. As reported in Breuste and Artmann (2014), they combine utility, social meaning, beauty and several ecosystem services such as food supply (Drescher 2004), air filtering (Davies et al. 2011), urban temperature and climate regulation (Phelan et al. 2015), noise reduction (Aylor 1972), runoff mitigation (Zhang et al. 2012) and biodiversity development (Lin et al. 2015). However, plant cultivation within cities may present environmental risks associated to both air and soil pollution (Alloway 2004). In urban areas, air pollutants are generally derived from artificial sources, e.g. vehicular emissions and fossil fuel burning (Agrawal et al. 2003). Urban air pollution has increased rapidly in the past decades with fast industrialization, rapid growth of urban population, increase in vehicular traffic, badly maintained roads and human activities. Consequently, agricultural land adjacent to urban areas may be exposed to air pollutants of urban origin, which may result in contamination of horticultural products beyond precautionary values. When this happens, a dietary exposure to trace metals can result in significant human health risk (Massaquoi et al. 2015). An interesting study (Säumel et al. 2012) explored the relationship between local traffic burden and the trace metal concentration in the edible biomass of different horticultural crops cultivated by gardeners in the inner city of Berlin, Germany, analysing the influence of traffic 
burden and of the existence of barriers between cultivation sites and nearby streets. The study shows that a higher overall traffic burden increases trace metal content in the crop biomass while the presence of barriers between cultivation site and roads strongly reduces trace metal content. As reported in Vittori Antisari et al. (2015), the concentration of trace metals in urban-grown vegetables is strictly related to the site in the city where plants are grown, with vegetables grown nearby main roads generally presenting the greatest pollution levels. Urban soils can also be contaminated as they are often located on old urban sites, impacted by human activities, such as industrial activities, road traffic, waste dumps and demolition sites (Jean-Soro et al. 2015). They may contain hazardous substances that can be assimilated by plants grown in these spaces and become a danger for human health. Among major pollutants in urban soils, potential toxic elements (As, $\mathrm{Hg}, \mathrm{Cd}$, $\mathrm{Co}, \mathrm{Cr}, \mathrm{Cu}, \mathrm{Mn}, \mathrm{Mo}, \mathrm{Ni}, \mathrm{Pb}, \mathrm{Sn}, \mathrm{Zn}$ and $\mathrm{Se}$ ) can be accumulated in foodstuffs and enter into the food chain, causing serious problems to human health. Most important sources of trace metals in urban soils are atmospheric depositions, agricultural input (e.g. fertilizers, pesticides and manure), use of low-quality compost, industrial activities and refineries. Exposure to metals can occur through a variety of processes. For As and Cd, intake of plant-derived food represents a major fraction of potentially health-threatening human exposure (Clemens and Ma 2016).

In Europe, urban gardens are primarily managed by the elders using traditional management practices often related to the wide use of synthetic products, mainly fertilizers, herbicides and pesticides (Szolnoki et al. 2013). One of the main problems that are encountered is the contamination risk associated with weed and pest control, generally managed by application of chemicals. In 2001, a study showed that about $90 \%$ of the German allotment holders use pesticides (UM 2014). Pesticides kill pests, but they may have a negative effect on the useful garden fauna (e.g. pollinators, pest predators) and may cause water, air and soil pollution as well as contamination of the edible products. Consistently, in recent years, the use of pesticides is being reduced or even completely banned in allotment gardens and their application has been dramatically reduced as gardener awareness has grown (Barthel et al. 2010). Soil fertilization, on the other hand, is generally applied by mineral inorganic fertilizers, which are easy to apply and allow the supply of the right dose of nutrients. However, cases of over-application and soil and water contamination by nitrates and phosphates have been repeatedly reported in urban gardens, due to the low agricultural skills of hobby farmers (Tixier and de Bon 2006). However, the potentially high environmental impact related to the considerable amount of inputs needed to support the production may be avoided when sustainable practices are adopted. Weed management may be addressed by using organic mulching, therein also improving moisture retention and preservation of soil fertility. Pest control may be addressed in different ways (Voigt et al. 2016), including selection of disease and pestresistant plants, adoption of companion plantings, using trap crop plants that attract pest insects saving the nearby main crop, application of natural insecticides (e.g. Neem oil and Pyrethrum), application of pests' diseases (e.g. Bacillus thuringiensis) and integration in the garden of flowering plants that attract beneficial insects (both pollinators and natural pest enemies). Organic fertilization (e.g. by using manure from livestock or poultry, or compost from vegetable waste) has the function of preserving soil characteristics allowing the proper crop development (Tixier and de Bon 2006). Organic fertilizers are characterized by slow and long-lasting action and have beneficial effects on soil microflora, soil texture and water holding capacity.

With the increase of world urban population, which in 2007 has surpassed the rural population, the surface of the city grows and evolves often uncontrollably. This leads to a continuous increase in impervious surfaces and the consequent consumption of arable soils. In such conditions, urban horticulture development follows a growing trend, representing not only a source of food but also becoming a possible source of income (Caldeyro-Stajano 2004). The two main constraints to the spread of urban horticulture are the shortage of soil and water. Soil in the cities may be contaminated by air and soil pollutants; therefore, cultivation of edible products may not be feasible and, in general, in the cities, often the availability of land is scarce (Orsini et al. 2013). In addition, water availability constitutes a further problem in the urban environment, since in some areas, there can be difficult access to drinking water. The adoption of simplified soilless cultivation systems allows overcoming these constraints (Tixier and de Bon 2006). Among the different soilless systems, the most commonly adopted in urban gardens are those that make use of solid substrates in containers generally built on wood and waterproofed with a plastic film (Orsini et al. 2014). The aim of the hereby illustrated research is to propose alternative/innovative agricultural techniques instead of those typically used by local gardeners (on soil cultivation with mineral or organic fertilizers purchased in local shops). Consistently, the risk of trace metal contamination in vegetables cultivated in an experimental urban allotment garden was investigated by comparing different growing systems (soil and soilless) and fertilization managements (mineral and organic).

\section{Materials and methods}

The experimental allotment garden was previously identified (Vittori Antisari et al. 2015) as the most contaminated by trace metals in terms of both tissue accumulation and leaf deposition in comparison with other allotment gardens situated in different areas of the city and nearby different sources of 
contamination. The experimental allotment garden (Fig. 1, with a surface of $40 \mathrm{~m}^{2}$ ) is part of a large area of gardens (so-called Orti Salgari), built in the 1980s, which occupies a surface of $27,000 \mathrm{~m}^{2}$ and is composed of 398 allotment gardens. It is situated nearby a main road of the city of Bologna (via San Donato, $300 \mathrm{~m}$ from the garden, $10^{3}-$ $10^{4}$ vehicles day ${ }^{-1}$ ), the main motorway (A14, $1200 \mathrm{~m}$ from the garden, $10^{5}$ vehicles day $\left.{ }^{-1}\right)$ and the railway $(1600 \mathrm{~m}$ from the garden, 700 trains day ${ }^{-1}$ ), and it is placed $10 \mathrm{~m}$ from the local street (coordinates $44^{\circ} 30^{\prime} 54^{\prime \prime} \mathrm{N}, 11^{\circ} 23^{\prime} 29^{\prime \prime} \mathrm{E}$ ). Moreover, the city incinerator (Frullo, $600 \mathrm{t} \mathrm{day}^{-1}$ of processed urban waste) is located $3000 \mathrm{~m}$ away, north-east of the garden, with prevailing winds in the east direction.

\subsection{Plant material and experimental design}

Seven experiments were conducted between June and November 2015. Plant species used were tomato (Lycopersicon esculentum cv. San Marzano), sweet basil (Ocimum basilicum cv. Napoletano), onion (Allium cepa cv. Gialla di Stoccarda), lettuce (Lactuca sativa cv. Four Seasons), kale (Brassica oleracea var. acephala or Tuscan kale or black cabbage), Florence/bulb fennel (Foeniculum vulgare var. azoricum cv. Carmo F1) and radish (Raphanus sativus cv. Cherry Bell). Plant density was 5 plants $\mathrm{m}^{-2}$ for kale and tomato; 10 plants $\mathrm{m}^{-2}$ for fennel, lettuce and basil; 25 plants $\mathrm{m}^{-2}$ for radish; and 35 plants $\mathrm{m}^{-2}$ for onion.

Treatments included growing media (soil vs peat) and fertilization management (mineral vs organic). Experimental design was a strip plot with two replicates with growing media in the main plot and fertilization management in the elemental plot. Each elemental plot hosted at least six plants.

\subsection{Growing conditions}

Some species (basil, tomato and radish) were sown in plastic containers filled with peat at the experimental greenhouse facilities of the Agricultural Sciences Department of the University of Bologna under controlled environmental conditions $\left(25{ }^{\circ} \mathrm{C}\right.$ and $50 \%$ relative humidity). As they reached adequate growth (June 5 for basil and tomato and September 28 for radish at 50,28 and 10 days, respectively, after sowing), seedlings were transplanted at the experimental allotment garden. Other species (lettuce, onion, kale, fennel) were purchased from a local retailer of products for agriculture (normally used by local gardeners, Garden Cap, Cadriano, BO, Italy) and transplanted at the experimental allotment garden (on June 5 for onion and on September 18 for lettuce, kale and fennel). Irrigation was provided daily with a drip irrigation system, supplying 9 and $6 \mathrm{~L} \mathrm{~m}^{-2}$ day $^{-1}$ in the summer (June to September) and early fall (October), respectively. Later on in the season (November), irrigation was not supplied.

Plants were grown either on the allotment soil or onto elevated beds filled with commercial soil (Geotec, RO, Italy). Growing containers were built according to Orsini et al. (2014), using recycled pallets and black plastic films. The declared physical and biochemical features of commercial soil were organic carbon $25 \%$, organic nitrogen $1 \%$, peat $60 \%$ and salinity $0.6 \mathrm{dS} \mathrm{m}^{-1}$.
Fig. 1 Location of the experimental garden $(X)$ in respect to main pollution sources, namely the city incinerator $(I)$, via San Donato $(R)$, A14 motorway $(M)$ and main railway $(T)$

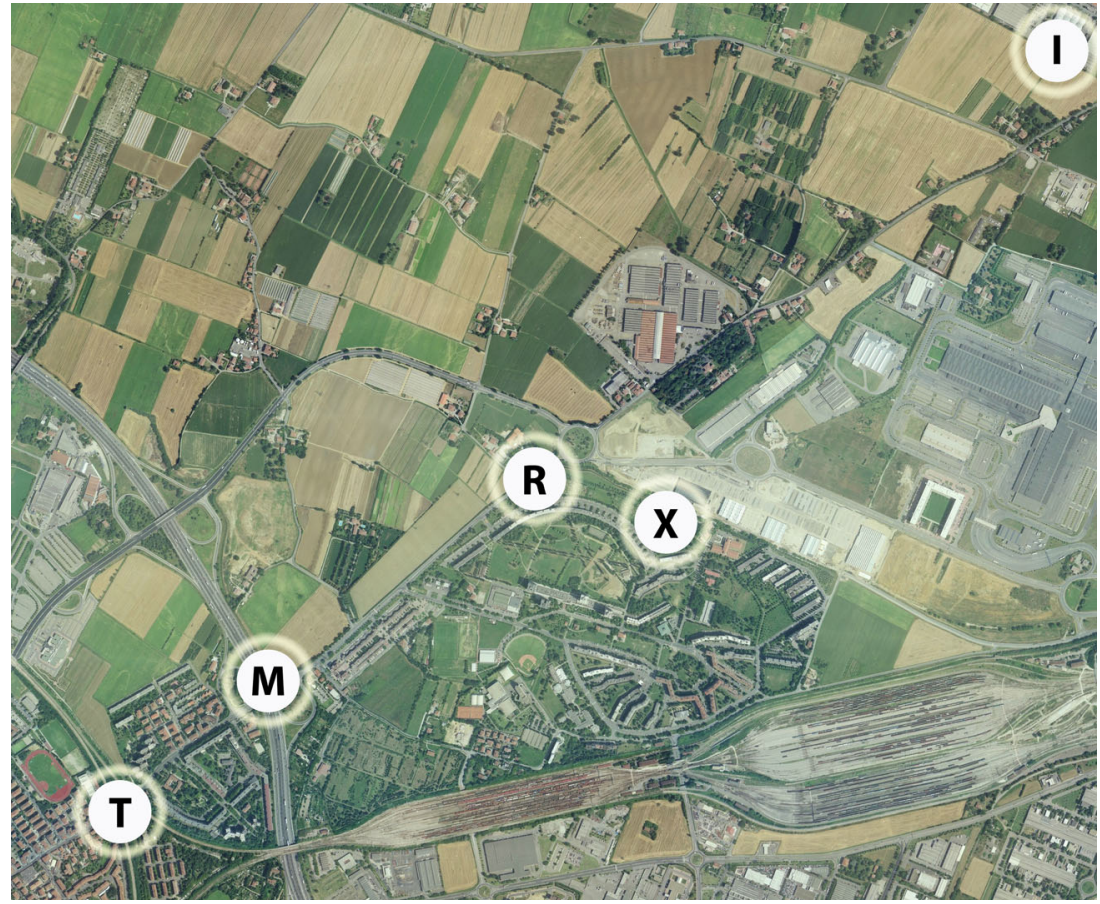


No pest control treatments were applied during the crop cycle. Consistently, organic and conventional management protocols were diversified only according to the plant nutrient management. Plants grown under mineral fertilization management were supplied with an N/P/K (5:7:14) chemical fertilizer (Tris, produced by ALFE, MN, Italy), in a measure of $50 \mathrm{~g} \mathrm{~m}^{-2}$. Organic crop management was obtained by adding $125 \mathrm{~g} \mathrm{~m}^{-2}$ of mature horse manure (Fertistall pellet, Agrilinea, FE, Italy), with the following declared features: nitrogen $2 \%$ and organic carbon $24 \%$. The different doses of fertilizer were calculated to give the same amount of nitrogen in the two treatments.

\subsection{Chemical analyses}

Soil and peat analysis Prior to experimentation, after the applications of the different fertilizers, soil and peat samples were collected and analysed as reported below. The samples were air-dried and sieved ( $<2 \mathrm{~mm}$ ). Measures of $\mathrm{pH}$ ( $\mathrm{pH}$ meter, Crison, Barcelona, Spain) were performed with distilled water on 1:2.5 w/v. Total organic carbon was measured by Dumas combustion with an EA $1110 \mathrm{CHN}$ elemental analyser (Thermo Fisher Scientific, Waltham, MA, USA) after dissolution of carbonates with $2 \mathrm{M} \mathrm{HCl}$, and the organic matter was obtained using 1.72 factors. Soil particle size distribution was determined by the pipette method (Gee and Bauder 1986), and total carbonates $\left(\mathrm{CaCO}_{3}\right)$ were quantified by a volumetric method, according to Dietrich-Fruhling.

The metal contents were determined according to Vittori Antisari et al. (2013). Briefly, the soil (0.25 g) was treated with aqua regia $\left(2 \mathrm{~mL}\right.$ of $65 \% \mathrm{HNO}_{3}$ plus $6 \mathrm{~mL}$ of $37 \%$ Suprapur $\mathrm{HCl}$, Suprapur grade; Carlo Erba, MI, Italy) in a microwave oven, and the metal concentrations were determined by inductively coupled plasma optical emission spectrometry (ICPOES). The analysis of each sample was replicated three times and compared with the analyses of the International Reference Materials (BCR 141) and laboratory internal standards (MO and ML), which was run after every ten samples to check changes in sensitivity. Controls with only reagents were also determined.

Vegetable sample collection and analysis At full maturity (at 38, 76, 76, 69, 69, 69 and 60 days after transplanting for basil, tomato, onion, lettuce, kale, fennel and radish, respectively), the samples of the different plant organs (roots, bulbs, stems, leaves, fruits) were collected for biochemical determinations. At harvest, fresh weights were recorded and dry weights were determined after washing in tap water and drying at $58^{\circ} \mathrm{C}$ per $72 \mathrm{~h}$. The samples were dried in a ventilated oven $\left(T<40^{\circ} \mathrm{C}\right)$ and ground in a blender with blades made of pure titanium, carefully avoiding to introduce any further metal contamination to the samples (Vittori Antisari et al. 2012). Briefly, approximately $0.25 \mathrm{~g}$ of the leaf sub-sample, weighted in Teflon bombs, was dissolved in $8 \mathrm{~mL}$ of $\mathrm{HNO}_{3}$ (Suprapur, Merck, Kenilworth, NJ, USA) plus $2 \mathrm{~mL}$ of $\mathrm{H}_{2} \mathrm{O}_{2}$ (Carlo Erba, MI, Italy) using a microwave oven (Milestone 2100, Sorisone, BG, Italy). After cooling, the solutions were made up to $20 \mathrm{~mL}$ with Milli-Q water and then filtered with a Whatman 42 filter paper. The major and trace elements were determined by ICP-OES (Spectro Ametek, MI, Italy). The ICP-OES setting followed multi-standard solutions (CPI International, Amsterdam, The Netherlands) that reproduce the matrix effect present in samples and allow the lowering of detection limits. Instrument response was assessed by measuring a standard sample (CRM 482, Community Bureau of Reference, BCR).

Statistical analysis The experimental data were statistically analysed using the two-way analysis of variance (ANOVA), and the means of field replicates $(n=6)$ were compared using the least significant difference (LSD) test.

\subsection{Contamination indexes}

Bioaccumulation factor For the different trace metals, the bioaccumulation factor (BAF) was calculated by (Eq. 1)

$\mathrm{BAF}=C_{\text {shoot }} / C_{\text {soil }}$

where $C_{\text {shoot }}$ and $C_{\text {soil }}$ are the metal concentration in the plant edible portion of the shoot ( $\mathrm{mg} \mathrm{kg}^{-1}$ dry weight) and soil (mg kg ${ }^{-1}$ dry weight), respectively (Ma et al. 2001; Cluis 2004).

Translocation factor Trace metal translocation from root to shoot was measured by the translocation factor (TF) calculated as described below (Eq. 2):

$\mathrm{TF}=C_{\text {shoot }} / C_{\text {root }}$

where $C_{\text {shoot }}$ and $C_{\text {root }}$ are the metal concentration in the edible part of the shoot ( $\mathrm{mg} \mathrm{kg}^{-1}$ dry weight) and the one of the root of the plant ( $\mathrm{mg} \mathrm{kg}^{-1}$ dry weight), respectively. Whenever $C_{\text {shoot }}$ is equal or greater than $C_{\text {root }}(\mathrm{TF}>1)$, metals are effectively translocated from root to the shoot, whereas root compartmentation occurs whenever $C_{\text {root }}$ is greater than $C_{\text {shoot }}$ (Baker and Brooks 1989; Zhang et al. 2002; Fayiga and Ma 2006).

Daily metal intake and health risk index The daily metal intake and health risk index are indexes related to daily estimated consumption as well as health risks from the consumption of contaminated food. The US Environmental Protection Agency's reference doses (US-EPA IRIS 2006) were used as reference points. The daily metal intake (DMI) was estimated using Eq. 3

$\mathrm{DMI}=C_{\text {shoot }} \times 0.085 \times \mathrm{DPC} / \mathrm{BW}$

where $C_{\text {shoot }}$ is the concentration of metals in the edible part of the shoot of the plant (as $\mathrm{mg} \mathrm{kg}^{-1}$ dry weight) multiplied by a 
conversion factor of 0.085 to convert dry weight vegetable metal content to fresh weight, according to Rattan et al. (2005). Daily plant consumption (DPC) and body weight (BW) were estimated based on Leclercq et al. (2009).

Based on the daily metal intake, it was possible to calculate the health risk index, based on Eq. 4

$\mathrm{HRI}=\mathrm{DMI} / \mathrm{RfD}$

where RfD is the reference dose, which, for the studied elements, is respectively $1.5(\mathrm{Cr}), 0.04(\mathrm{Cu}), 0.004(\mathrm{~Pb})$ and 0.02 (Ni) (mg kg ${ }^{-1} \mathrm{BW} \mathrm{day}^{-1}$ ) (US-EPA IRIS 2006; Jan et al. 2010). HRI values $>1$ are considered to pose health risks (Cui et al. 2004; Rattan et al. 2005).

\section{Results and discussion}

\subsection{Growing media characteristics and metal concentrations}

Soil $\mathrm{pH}$ measured in the top $20-\mathrm{cm}$ layer was significantly $(p<0.001)$ higher than that of peat (Table 1). Fertilization management did not influence the $\mathrm{pH}$ of soil samples, whereas the $\mathrm{pH}$ of peat samples was statistically different in the two diverse fertilization methods with higher values on the samples treated with mineral fertilizer as compared to the organic ones (Table 1). The importance of this parameter is related to the influence that it has on all the reactions that occur in nature. The $\mathrm{pH}$ values of the soil encountered in the present study were in line with the regional average values that, in Emilia Romagna soils, present $\mathrm{pH}$ values between 7 and 8.5, classified as sub-alkaline soils (ARPA-RER 2004). The average $\mathrm{CaCO}_{3}$ total content in soil samples was significantly $(p<0.01)$ higher as compared to that in peat samples (+53\%), which was possibly correlated with the differences in $\mathrm{pH}$ (Rowell 2014). On the other hand, organic matter was ten times higher in peat samples as compared to that in soil samples (Table 1). Both the values of total carbonates and organic carbon (Table 1) measured for soil samples were in line with the average values of the regional soils. No statistical differences in macroelement content were observed between organic and mineral samples (Table 1). Significantly $(p<0.001)$ higher concentrations of $\mathrm{Al}, \mathrm{B}, \mathrm{Ba}, \mathrm{Fe}, \mathrm{K}$ and Mn were observed in soil samples; on the contrary, concentrations of $\mathrm{Ca}, \mathrm{Na}, \mathrm{S}$ and $\mathrm{Si}$ were significantly higher in peat samples (Table 1). No significant differences in $\mathrm{Mg}, \mathrm{P}, \mathrm{Sr}$ and Ti content were observed between soil and peat samples. Trace metal contents, however, widely varied between soil and peat samples. For every sample, the concentration of $\mathrm{Cd}$ was below the detection limit, and only for soil samples, Mo concentration was below the detection limit. Significant $(p<0.001)$ differences between soil and peat samples were
Table 1 Main soil features $\left(\mathrm{pH}, \mathrm{CaCO}_{3}\right.$, organic matter and organic $\left.\mathrm{C}\right)$ and concentrations of macroelements (expressed as $\mathrm{g} \mathrm{kg}^{-1}$ dry weight) and microelements (expressed as $\mathrm{mg} \mathrm{kg}^{-1}$ dry weight) in soil and peat samples added with organic fertilizer or mineral fertilizer

\begin{tabular}{|c|c|c|c|c|c|c|c|c|c|}
\hline \multirow[b]{3}{*}{$\mathrm{pH}\left(\mathrm{H}_{2} \mathrm{O}\right)$} & \multirow{3}{*}{$\begin{array}{c}\text { Unit } \\
-\end{array}$} & \multicolumn{4}{|l|}{ Peat } & \multicolumn{4}{|l|}{ Soil } \\
\hline & & \multicolumn{2}{|c|}{ Organic } & \multicolumn{2}{|c|}{ Mineral } & \multicolumn{2}{|c|}{ Organic } & Mineral & \\
\hline & & 6.72 & $\mathrm{c}$ & 6.88 & $\mathrm{~b}$ & 8.11 & $\mathrm{a}$ & 7.97 & \\
\hline $\mathrm{CaCO}_{3}$ & $\mathrm{~g} \mathrm{~kg}^{-1}$ & 35.15 & $\mathrm{~b}$ & 39.95 & $\mathrm{~b}$ & 59.9 & $\mathrm{a}$ & 55.05 & 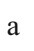 \\
\hline Organic Matter & $\%$ & 55.72 & $\mathrm{a}$ & 56.35 & $\mathrm{a}$ & 4.89 & $\mathrm{~b}$ & 4.77 & \\
\hline Organic $\mathrm{C}$ & $\%$ & 22.27 & $\mathrm{a}$ & 22.67 & $\mathrm{a}$ & 1.96 & $\mathrm{~b}$ & 1.90 & \\
\hline $\mathrm{Al}$ & $\mathrm{g} \mathrm{kg}^{-1}$ & 8.27 & $\mathrm{~b}$ & 6.89 & $\mathrm{~b}$ & 32.78 & $\mathrm{a}$ & 31.09 & \\
\hline B & $\mathrm{g} \mathrm{kg}^{-1}$ & 0.02 & $\mathrm{~b}$ & 0.02 & $\mathrm{~b}$ & 0.03 & $\mathrm{a}$ & 0.03 & \\
\hline $\mathrm{Ba}$ & $\mathrm{g} \mathrm{kg}^{-1}$ & 0.07 & $\mathrm{~b}$ & 0.07 & $\mathrm{~b}$ & 0.20 & $\mathrm{a}$ & 0.19 & \\
\hline $\mathrm{Ca}$ & $\mathrm{g} \mathrm{kg}^{-1}$ & 29.34 & $\mathrm{a}$ & 27.42 & $\mathrm{a}$ & 22.76 & $\mathrm{~b}$ & 23.29 & t \\
\hline $\mathrm{Fe}$ & $\mathrm{g} \mathrm{kg}^{-1}$ & 8.28 & $\mathrm{~b}$ & 7.27 & $\mathrm{~b}$ & 24.47 & a & 24.32 & \\
\hline K & $\mathrm{g} \mathrm{kg}^{-1}$ & 6.04 & $\mathrm{~b}$ & 5.02 & $\mathrm{~b}$ & 7.55 & a & 7.01 & \\
\hline $\mathrm{Mg}$ & $\mathrm{g} \mathrm{kg}^{-1}$ & 7.52 & ns & 6.70 & ns & 7.01 & ns & 7.04 & \\
\hline Mn & $\mathrm{g} \mathrm{kg}^{-1}$ & 0.25 & $\mathrm{~b}$ & 0.21 & $\mathrm{~b}$ & 0.77 & a & 0.76 & \\
\hline $\mathrm{Na}$ & $\mathrm{g} \mathrm{kg}^{-1}$ & 1.87 & $\mathrm{a}$ & 1.80 & $\mathrm{a}$ & 0.81 & $\mathrm{~b}$ & 0.72 & \\
\hline$P$ & $\mathrm{~g} \mathrm{~kg}^{-1}$ & 1.63 & ns & 1.59 & ns & 1.77 & ns & 1.73 & \\
\hline S & $\mathrm{g} \mathrm{kg}^{-1}$ & 1.14 & $\mathrm{a}$ & 1.21 & $\mathrm{a}$ & 0.17 & $\mathrm{~b}$ & 0.19 & \\
\hline $\mathrm{Si}$ & $\mathrm{g} \mathrm{kg}^{-1}$ & 0.28 & $\mathrm{a}$ & 0.26 & $\mathrm{a}$ & 0.08 & $\mathrm{~b}$ & 0.14 & \\
\hline $\mathrm{Sr}$ & $\mathrm{g} \mathrm{kg}^{-1}$ & 0.09 & ns & 0.10 & ns & 0.11 & ns & 0.11 & \\
\hline $\mathrm{Ti}$ & $\mathrm{g} \mathrm{kg}^{-1}$ & 0.57 & ns & 0.46 & ns & 0.63 & ns & 0.56 & \\
\hline As & $\mathrm{mg} \mathrm{kg}^{-1}$ & 3.63 & $\mathrm{~b}$ & 3.56 & $\mathrm{~b}$ & 6.81 & $\mathrm{a}$ & 7.23 & \\
\hline $\mathrm{Be}$ & $\mathrm{mg} \mathrm{kg}^{-1}$ & 0.36 & $\mathrm{~b}$ & 0.30 & $\mathrm{~b}$ & 1.43 & $\mathrm{a}$ & 1.39 & \\
\hline $\mathrm{Cd}$ & $\mathrm{mg} \mathrm{kg}^{-1}$ & $<\mathrm{DL}$ & & $<\mathrm{DL}$ & & $<\mathrm{DL}$ & & $<\mathrm{DL}$ & \\
\hline $\mathrm{Co}$ & $\mathrm{mg} \mathrm{kg}^{-1}$ & 4.71 & $\mathrm{~b}$ & 4.15 & $\mathrm{~b}$ & 13.13 & $\mathrm{a}$ & 12.78 & \\
\hline $\mathrm{Cr}$ & $\mathrm{mg} \mathrm{kg}^{-1}$ & 38.70 & $\mathrm{~b}$ & 41.44 & $\mathrm{~b}$ & 93.50 & $\mathrm{a}$ & 87.98 & \\
\hline $\mathrm{Cu}$ & $\mathrm{mg} \mathrm{kg}^{-1}$ & 37.98 & $\mathrm{~b}$ & 34.56 & $\mathrm{~b}$ & 56.46 & $\mathrm{a}$ & 56.13 & \\
\hline $\mathrm{Li}$ & $\mathrm{mg} \mathrm{kg}^{-1}$ & 12.08 & $\mathrm{~b}$ & 10.52 & $\mathrm{~b}$ & 45.08 & $\mathrm{a}$ & 44.15 & \\
\hline Mo & $\mathrm{mg} \mathrm{kg}^{-1}$ & 4.27 & $\mathrm{a}$ & 4.01 & $\mathrm{a}$ & $<\mathrm{DL}$ & & $<\mathrm{DL}$ & \\
\hline $\mathrm{Ni}$ & $\mathrm{mg} \mathrm{kg}^{-1}$ & 17.82 & $\mathrm{~b}$ & 15.31 & $\mathrm{~b}$ & 46.03 & $\mathrm{a}$ & 45.54 & \\
\hline $\mathrm{Pb}$ & $\mathrm{mg} \mathrm{kg}^{-1}$ & 18.96 & $\mathrm{~b}$ & 15.15 & $\mathrm{~b}$ & 48.66 & $\mathrm{a}$ & 40.12 & \\
\hline $\mathrm{Sb}$ & $\mathrm{mg} \mathrm{kg}^{-1}$ & 1.30 & $\mathrm{~b}$ & 1.30 & $\mathrm{~b}$ & 1.53 & a & 1.43 & \\
\hline $\mathrm{Sn}$ & $\mathrm{mg} \mathrm{kg}^{-1}$ & 1.44 & $\mathrm{~b}$ & 1.41 & $\mathrm{~b}$ & 4.30 & $\mathrm{a}$ & 3.75 & \\
\hline V & $\mathrm{mg} \mathrm{kg}^{-1}$ & 19.44 & $\mathrm{~b}$ & 16.32 & $\mathrm{~b}$ & 65.61 & $\mathrm{a}$ & 63.46 & \\
\hline $\mathrm{Zn}$ & $\mathrm{mg} \mathrm{kg}^{-1}$ & 74.13 & $\mathrm{~b}$ & 71.01 & $\mathrm{~b}$ & 106.3 & a & 108.8 & \\
\hline
\end{tabular}

Different letters indicate significant differences within the row at $p \leq 0.05$; ns indicates non-significant differences at $p \leq 0.05(n=6)$

revealed for each of the other microelements (As, Be, Co, $\mathrm{Cr}, \mathrm{Cu}, \mathrm{Li}, \mathrm{Mo}, \mathrm{Ni}, \mathrm{Pb}, \mathrm{Sb}, \mathrm{Sn}, \mathrm{V}, \mathrm{Zn}$ ), with greater values in soil samples (Table 1). Comparing average soil microelement concentrations with results of other researches in both urban and rural environments, the first consideration is that trace metal concentration in soils may vary substantially according to both geogenic and anthropic elements. As compared with other studies (Luo et al. 2011; Szolnoki et al. 2013; Izquierdo et al. 2015), the soil Cr content hereby 
measured (91 mg kg-1, Table 1) turned out to be higher than previous evidences in urban gardens where it ranged 12 to $31 \mathrm{mg} \mathrm{kg}^{-1}$. Alternatively, $\mathrm{Cu}, \mathrm{Pb}$ and $\mathrm{Ni}$ (accounting for 56,44 and $46 \mathrm{mg} \mathrm{kg}^{-1}$, respectively, Table 1) were within previously observed concentrations (Kabala et al. 2009; Luo et al. 2011; Szolnoki et al. 2013; Jean-Soro et al. 2015; Izquierdo et al. 2015) in both urban and rural environments.

\subsection{Trace metal content in vegetables edible portions}

Although potential health risks are generally associated with the assimilation of trace metals, there is a lack in legislation concerning threshold limits for most trace metals in marketed crops. The only available EU legislation (EU 2009) regulates upper limits of $\mathrm{Pb}$ and $\mathrm{Cd}$ in edible products. Consistently, $\mathrm{Pb}$ shall always be under $0.1,0.3$ and $0.2 \mathrm{mg} \mathrm{kg}^{-1}$ of fresh weight (in legumes, brassica and all other vegetables, respectively), which are about 1.2, 2.4 and $3.6 \mathrm{mg} \mathrm{kg}^{-1}$ on a dry weight basis. Furthermore, $\mathrm{Cd}$ threshold limits are set at $0.05,0.1$ and $0.2 \mathrm{mg} \mathrm{kg}^{-1}$ of fresh weight in vegetables whose edible part is the fruit, the stem/root or the leaf, respectively (EU 2009). The most dangerous elements beyond $\mathrm{Pb}$ and $\mathrm{Cd}$ are $\mathrm{Cr}, \mathrm{Cu}, \mathrm{As}$ and $\mathrm{Ni}$ (Vittori Antisari et al. 2015). Within the experiments hereby described, some of these elements (namely $\mathrm{Cd}$ and As) were not detectable in vegetable samples. On the other hand, significant accumulation levels of $\mathrm{Cr}, \mathrm{Cu}, \mathrm{Pb}$
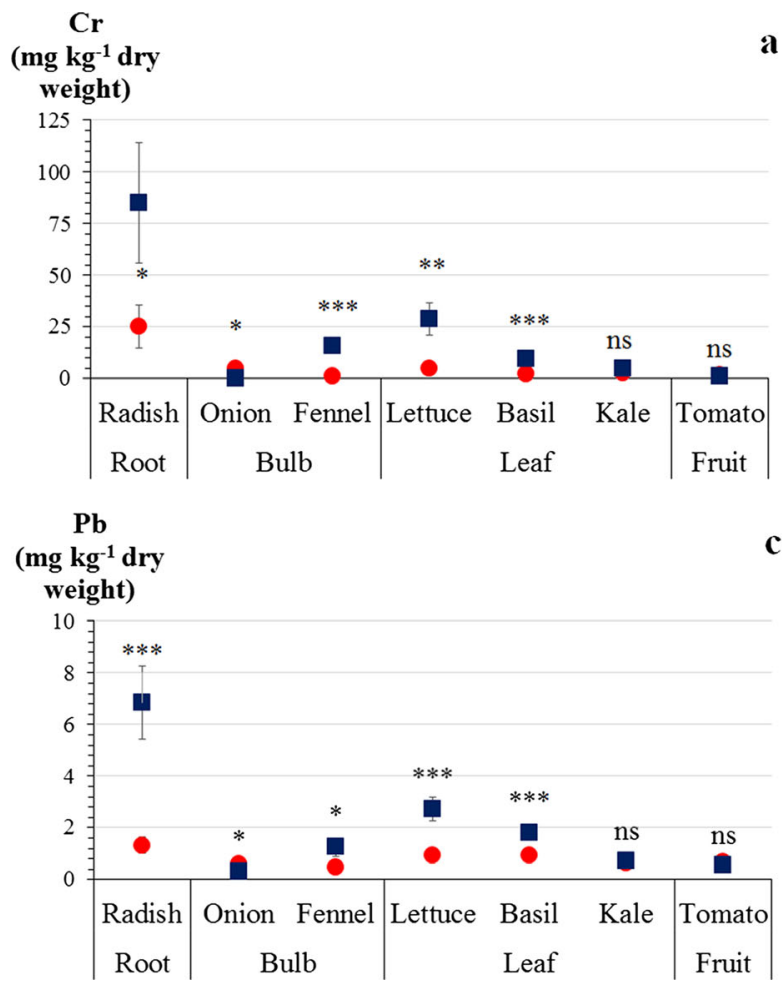

Fig. 2 Accumulation of $\mathrm{Cr}(\mathbf{a}), \mathrm{Cu}(\mathbf{b}), \mathrm{Pb}(\mathbf{c})$ and $\mathrm{Ni}(\mathbf{d})$ (expressed in $\mathrm{mg} \mathrm{kg}^{-1}$ dry weight) in edible portions of radish, onion, fennel, lettuce, basil, kale and tomato according to the growing system (soilless on peat in red or traditional on soil in blue). Vertical bars represent standard and Ni were found, as shown in Figs. 2 and 3. The recovery intervals for these elements, based on the CRM 482, were respectively $3.99 \pm 0.51(\mathrm{Cr}), 7.03 \pm 0.19(\mathrm{Cu}), 2.19 \pm 0.49$ $(\mathrm{Ni})$ and $37.8 \pm 1.47(\mathrm{~Pb})$. Given that no significant interaction between the growing system and fertilization management on the edible product content of those trace metals was observed, the effects of these two factors will be separately described for each element.

Chromium $\mathrm{Cr}$ content in edible organs of radish, fennel, lettuce and basil was significantly higher in plants cultivated on soil as compared to those grown in peat, with the greatest values in radish and lettuce ( 85 and $29 \mathrm{mg} \mathrm{kg}^{-1}$, respectively) (Fig. 2a). Contrariwise, $\mathrm{Cr}$ accumulation in onion bulbs was higher in plants cultivated on peat. Finally, kale leaves and tomato fruit did not present significant differences between the two growing systems (Fig. 2a). Based on the fertilization managements (Fig. 3a), Cr accumulation was higher in the samples of radish, onion, lettuce and tomato supplied with organic fertilizer. The highest concentrations were observed in radish and lettuce reaching 76 and $26 \mathrm{mg} \mathrm{kg}^{-1}$, respectively. No significant differences could be associated with fertilization management in fennel, basil or kale (Fig. 3a).

Copper $\mathrm{Cu}$ content in edible organs of radish, onion, fennel, lettuce, basil and tomato was significantly higher in plants

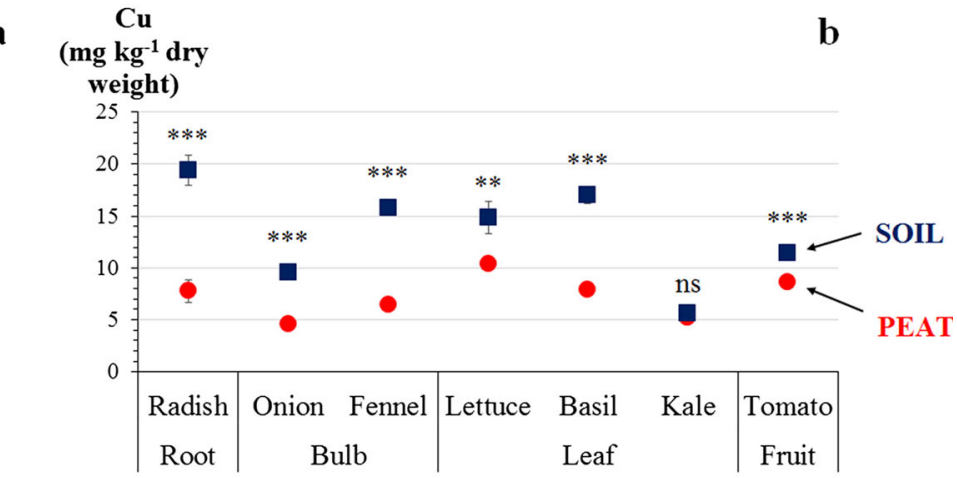$$
\mathrm{Ni}
$$
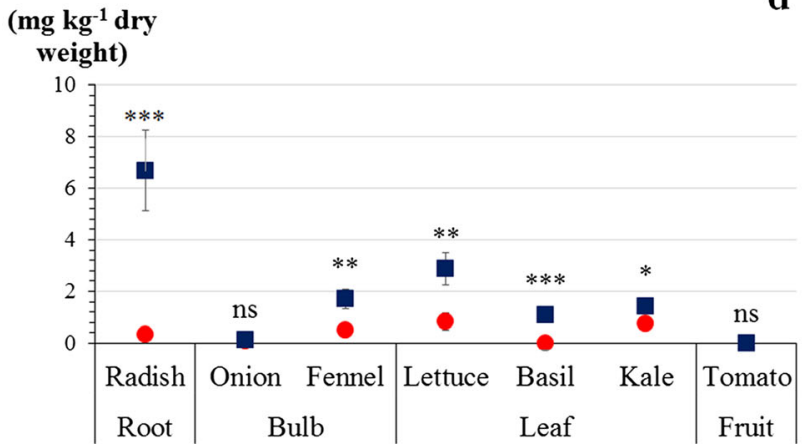

deviation. Asterisk symbols indicate significant differences at $* p \leq 0.05$, $* * p \leq 0.01$ or $* * * p \leq 0.001$, whereas $n s$ indicates non-significant differences at $p \leq 0.05(n=6)$ 


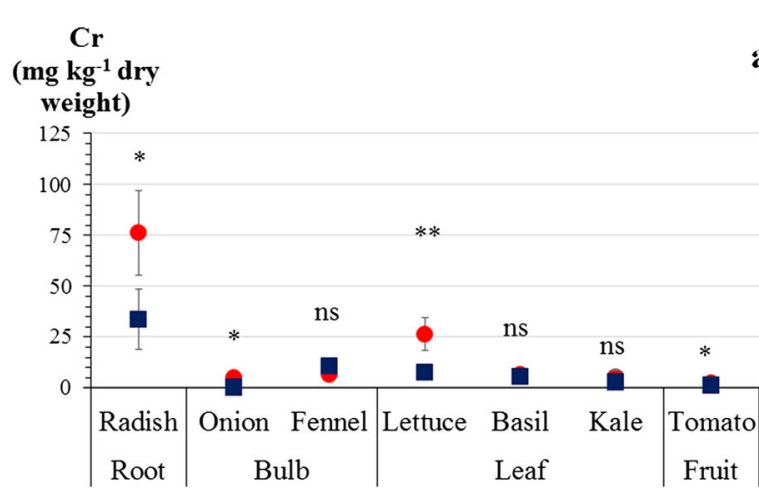

a
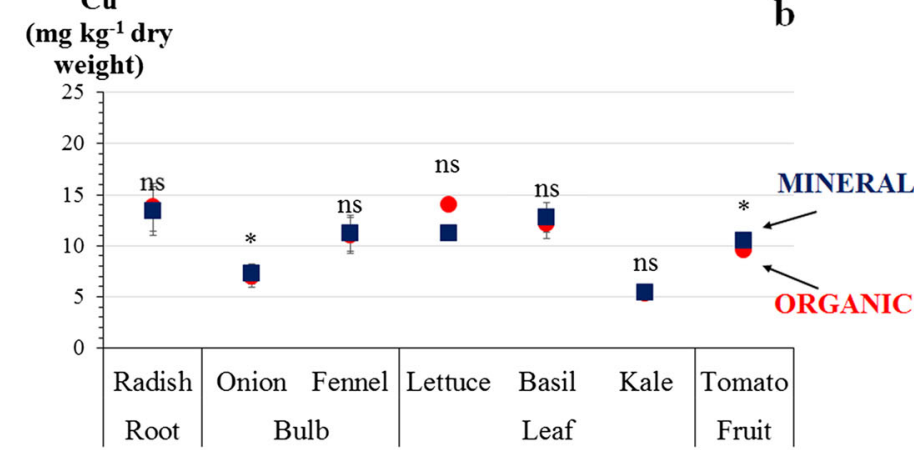

$\mathbf{P b}$

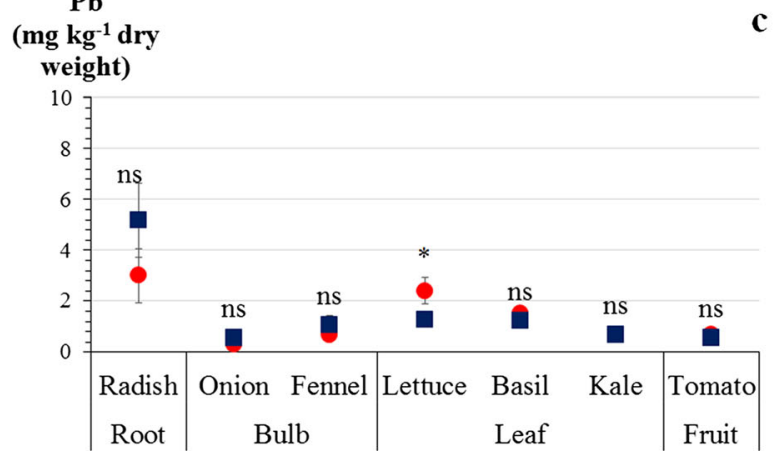

Fig. 3 Accumulation of $\mathrm{Cr}(\mathbf{a}), \mathrm{Cu}(\mathbf{b}), \mathrm{Pb}(\mathbf{c})$ and $\mathrm{Ni}(\mathbf{d})$ (expressed in $\mathrm{mg} \mathrm{kg}{ }^{-1}$ dry weight) in edible portions of radish, onion, fennel, lettuce, basil, kale and tomato according to fertilization management (organic in red and mineral in blue). Vertical bars represent standard deviation.

cultivated on soil as compared to those grown in peat, with the greatest values in radish and basil (19 and $17 \mathrm{mg} \mathrm{kg}^{-1}$, respectively) (Fig. 2b). No statistically significant differences could be observed in leaves of soil- and peat-grown plants of kale, which also showed the lowest concentration $\left(5 \mathrm{mg} \mathrm{kg}^{-1}\right)$ among the studied species grown in soil (Fig. 2b). Considering fertilization management, significant differences in $\mathrm{Cu}$ accumulation were detectable only in onion bulbs and tomato fruits, with a slightly higher $(+4$ and $+1 \%$, respectively) concentration in plants grown with mineral fertilizer as compared to the same products supplied with organic fertilization (Fig. 3b). The highest concentrations were observed in radish and lettuce (14 $\left.\mathrm{mg} \mathrm{kg}^{-1}\right)$ (Fig. 3b).

Lead $\mathrm{Pb}$ content in edible parts of radish, fennel, lettuce and basil was significantly higher in plants cultivated on soil than those cultivated on peat (Fig. 2c), with values above EU safety thresholds only observed in radish. Contrariwise, onion showed opposite results, with $\mathrm{Pb}$ accumulation being greater in onion cultivated on peat as compared to the same plants grown in soil (Fig. 2c). In general, radish and lettuce had the higher accumulation level ( 7 and $3 \mathrm{mg} \mathrm{kg}^{-1}$, respectively). Kale and tomato fruit did not present significant differences between the two growing systems. Fertilization management did not affect $\mathrm{Pb}$ content in edible tissues of the studied species, with exclusion of lettuce, where a significant twofold

\section{$\mathrm{Ni}$}

$\left(\mathrm{mg} \mathrm{kg}^{-1} \mathrm{dry}\right.$

weight)

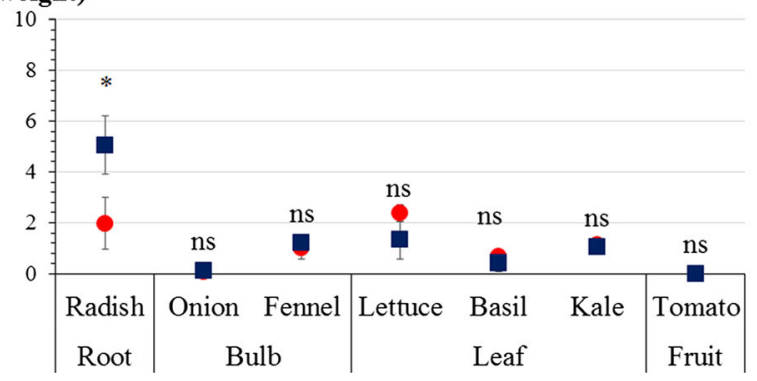

Asterisk symbols indicate significant differences at $* p \leq 0.05$, $* * p \leq 0.01$, whereas $n s$ indicates non-significant differences at $p \leq 0.05$ $(n=6)$

increase in $\mathrm{Pb}$ content was associated with organic fertilization regime (Fig. 3c).

Nickel Ni content in edible organs of radish, fennel, lettuce, basil and kale was significantly higher in plants cultivated on soil as compared to those grown in peat, with the greatest values in radish and lettuce ( 7 and $3 \mathrm{mg} \mathrm{kg}^{-1}$, respectively) (Fig. 2d). Independent from the growing system, the lowest accumulations were observed in onion $\left(0.10 \mathrm{mg} \mathrm{kg}^{-1}\right)$ and tomato $\left(0 \mathrm{mg} \mathrm{kg}^{-1}\right)$ (Fig. 2d). Fertilization management did not affect Ni content in edible tissues of the studied species, with exclusion of radish, where a 2.5 -fold increase in Ni content was associated with mineral fertilization regime (Fig. 3d).

In order to understand the potential health risk of the vegetables grown in the allotment garden, a comparative analysis against values obtained in previous similar studies (Douay et al. 2013; Säumel et al. 2012; Warming et al. 2015) was performed. Accordingly and despite the apparently high content in soils, $\mathrm{Cr}$ values were relatively low (with exclusion of radish that most accumulated $\mathrm{Cr}$, with values of $85 \mathrm{mg} \mathrm{kg}^{-1}$, Fig. 2). On the other hand, $\mathrm{Cu}$ and $\mathrm{Ni}$ values were generally higher than previous experiences and $\mathrm{Pb}$ values varied dramatically across species (with the greatest values again on radish, about $7 \mathrm{mg} \mathrm{kg}^{-1}$, Fig. 2). A previous study (Säumel et al. 2012) addressed the quantification of trace metal contaminants in 
allotment gardens and food purchased at local markets in the city of Berlin, showing lower values of $\mathrm{Cu}$ and $\mathrm{Ni}$ as compared to the hereby presented results. This suggests that crops able to better exclude or compartmentalize those two elements should be preferred at the experimental site.

When the mean values of all studied vegetable species were compared, the adoption of simplified soilless systems filled with a non-contaminated growing substrate enabled to reduce trace metal contamination risk associated with $\mathrm{Cr}(-70 \%, 6$ vs $20 \mathrm{mg} \mathrm{kg}^{-1}$, in peat vs soil, respectively), $\mathrm{Cu}(-61 \%, 7 \mathrm{vs}$ $\left.13 \mathrm{mg} \mathrm{kg}^{-1}\right), \mathrm{Pb}\left(-45 \%, 0.8\right.$ vs $\left.2.0 \mathrm{mg} \mathrm{kg}^{-1}\right)$ and $\mathrm{Ni}(-81 \%$, 0.3 vs $\left.2 \mathrm{mg} \mathrm{kg}^{-1}\right)$. Apparently, the greater values of contaminants associated with on-soil cultivation should be related to the growing media content (Table 1). Furthermore, the observed differences found in the $\mathrm{pH}$ values of soil and peat (Table 1) may have influenced the toxic mineral uptake, given that substrate $\mathrm{pH}$ affects differently the solubility and availability of the elements, as commonly known (e.g. Kumpiene et al. 2008; Zeng et al. 2011).

Organic fertilization strategies did not affect substantially biochemical features and trace metal concentrations of the growing media, as illustrated in Table 1. In the present study, however, some crop-specific differences in trace metal accumulation in edible tissue were evidenced, with a general raise in $\mathrm{Cr}$ in radish and in $\mathrm{Cr}$ and $\mathrm{Pb}$ in lettuce grown under organic fertilization. On the other hand, mineral fertilization resulted in greater $\mathrm{Ni}$ in radish and $\mathrm{Cu}$ in onion and tomato. Comparative studies of organic versus mineral fertilization have rarely addressed the effect of trace metal accumulation (Chu and Wong 1987; Singh et al. 2010; Zaccone et al. 2010; Christensen and Elsgaard 2014), often with controversial results (Liñero et al. 2015). Consistently, a priority of the research is to address the understanding of how organic matter may affect (e.g. by chelating minerals) the plant uptake of contaminants.

\subsection{Trace metal contamination indexes}

In order to identify the crop capacity to exclude dangerous trace metals, the bioaccumulation factor was used to understand which species were most resilient to ion distribution in the growing media (Rezvani and Zaefarian 2011). Consistently, crops may be classified as hyperaccumulators, accumulators and excluders, based on the value of their bioaccumulation factor being above, equal or below 1 unit. Accordingly, all studied species acted as excluders, although to a different extent (Table 2). While the highest values were associated with radish roots, the lowest ones were observed for $\mathrm{Cr}$ and $\mathrm{Ni}$ in edible organs of tomato, confirming the plant capability to avoid toxic elements loading into fruits (Ali and
Table 2 Contamination indexes of soil-grown vegetables at the experimental site: bioaccumulation factor, translocation factor and health risk index for adults $(70 \mathrm{~kg}$ body weight and $0.22 \mathrm{~kg} \mathrm{day}^{-1}$ daily plant consumption) and children ( $26 \mathrm{~kg}$ body weight and $0.13 \mathrm{~kg} \mathrm{day}^{-1}$ daily plant consumption)

\begin{tabular}{|c|c|c|c|c|c|c|c|c|c|}
\hline \multirow[t]{2}{*}{ Element } & \multirow[t]{2}{*}{ Species } & \multicolumn{2}{|c|}{ Bioaccumulation factor } & \multicolumn{2}{|c|}{ Translocation factor } & \multicolumn{4}{|c|}{ Health Risk Index } \\
\hline & & & & & & Adult & & Childre & \\
\hline \multirow[t]{7}{*}{$\mathrm{Cr}$} & Fennel & 0.100 & $\mathrm{c}$ & - & & 0.003 & $\mathrm{e}$ & 0.006 & \\
\hline & Kale & 0.060 & $\mathrm{e}$ & 0.260 & $\mathrm{a}$ & 0.001 & $\mathrm{c}$ & 0.002 & \\
\hline & Lettuce & 0.210 & $\mathrm{~b}$ & - & & 0.005 & $\mathrm{~b}$ & 0.011 & \\
\hline & Onion & 0.060 & $\mathrm{f}$ & - & & 0.0001 & $\mathrm{~g}$ & 0.000 & \\
\hline & Radish & 0.780 & $\mathrm{a}$ & - & & 0.015 & $\mathrm{a}$ & 0.032 & \\
\hline & Basil & 0.080 & d & 0.260 & $\mathrm{a}$ & 0.002 & $\mathrm{~d}$ & 0.004 & \\
\hline & Tomato & 0.030 & $\mathrm{~g}$ & 0.440 & $\mathrm{a}$ & 0.0002 & $\mathrm{f}$ & 0.001 & \\
\hline \multirow[t]{7}{*}{$\mathrm{Cu}$} & Fennel & 0.220 & d & - & & 0.105 & $\mathrm{~g}$ & 0.219 & \\
\hline & Kale & 0.120 & $\mathrm{~g}$ & 0.330 & $\mathrm{c}$ & 0.037 & $\mathrm{c}$ & 0.078 & rata \\
\hline & Lettuce & 0.270 & $\mathrm{~b}$ & - & & 0.099 & $\mathrm{~d}$ & 0.206 & \\
\hline & Onion & 0.140 & $\mathrm{f}$ & - & & 0.064 & $\mathrm{f}$ & 0.133 & 1 \\
\hline & Radish & 0.270 & $\mathrm{a}$ & - & & 0.130 & $\mathrm{a}$ & 0.270 & 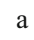 \\
\hline & Basil & 0.260 & $\mathrm{c}$ & 1.170 & $\mathrm{a}$ & 0.114 & $\mathrm{~b}$ & 0.236 & \\
\hline & Tomato & 0.220 & $\mathrm{e}$ & 0.520 & $\mathrm{~b}$ & 0.076 & $\mathrm{e}$ & 0.159 & \\
\hline \multirow[t]{7}{*}{$\mathrm{Pb}$} & Fennel & 0.020 & $\mathrm{~d}$ & - & & 0.084 & $\mathrm{e}$ & 0.174 & \\
\hline & Kale & 0.020 & $\mathrm{e}$ & 0.780 & $\mathrm{a}$ & 0.049 & $\mathrm{~d}$ & 0.102 & c \\
\hline & Lettuce & 0.050 & $\mathrm{~b}$ & - & & 0.182 & $\mathrm{~b}$ & 0.379 & $\mathrm{~b}$ \\
\hline & Onion & 0.020 & $\mathrm{~g}$ & - & & 0.019 & $\mathrm{~g}$ & 0.041 & \\
\hline & Radish & 0.110 & $\begin{array}{l}5 \\
\mathrm{a}\end{array}$ & - & & 0.457 & a & 0.951 & $\mathrm{a}$ \\
\hline & Basil & 0.040 & $\mathrm{c}$ & 0.750 & $\mathrm{a}$ & 0.121 & $\mathrm{f}$ & 0.252 & \\
\hline & Tomato & 0.020 & $\mathrm{f}$ & 0.390 & $\mathrm{~b}$ & 0.038 & $\mathrm{e}$ & 0.079 & \\
\hline \multirow[t]{7}{*}{$\mathrm{Ni}$} & Fennel & 0.030 & $\mathrm{~d}$ & - & & 0.023 & $\mathrm{a}$ & 0.048 & \\
\hline & Kale & 0.030 & $\mathrm{c}$ & 0.660 & $\mathrm{a}$ & 0.019 & a & 0.040 & \\
\hline & Lettuce & 0.050 & $\mathrm{~b}$ & - & & 0.038 & $\mathrm{a}$ & 0.080 & \\
\hline & Onion & 0.003 & $\mathrm{f}$ & - & & 0.002 & $\mathrm{a}$ & 0.004 & \\
\hline & Radish & 0.080 & $\mathrm{a}$ & - & & 0.089 & $\mathrm{a}$ & 0.186 & \\
\hline & Basil & 0.010 & $\mathrm{e}$ & 0.220 & $\mathrm{~b}$ & 0.014 & $\mathrm{a}$ & 0.030 & a \\
\hline & Tomato & 0.000 & g & 0.000 & $\mathrm{c}$ & 0.000 & $\mathrm{a}$ & 0.000 & \\
\hline
\end{tabular}

Different letters indicate significant differences at $p \geq 0.05(n=6)$ 
Al-Qahtani 2012). Once a toxic element enters in the plant by the root, it can either be translocated to shoots or compartmentalized within roots. An indicator of the plant ability to avoid translocation of such elements into shoot is provided by the translocation factor (Rezvani and Zaefarian 2011). The higher its value, the greater the rate of element that is transferred to shoots. Among studied crops, three species (kale, sweet basil and tomato) representing three different plant families (Brassicaceae, Lamiaceae and Solanaceae, respectively) were studied for their trace metal compartmentation in different plant organs (Table 2). For the sake of this publication, translocation factor was calculated by relating the element concentration in the edible plant organ (leaf or fruit) to the concentration of the same element in roots. Accordingly, no differences were observed on $\mathrm{Cr}$, whereas the greatest values of translocation factor for $\mathrm{Cu}$ were observed in sweet basil and for $\mathrm{Pb}$ and $\mathrm{Ni}$ in kale, confirming the hypothesis that the lowest translocation occurs to fruits as compared to leaves in plants (Tiwari et al. 2011). Consistently, a study over 15 plant native species grown in trace metal-contaminated sites in Florida showed that both $\mathrm{Pb}$ and $\mathrm{Cu}$ absorbed at the root level were only partially translocated to shoots (Yoon et al. 2006).

In order to better address the comprehension of the potential health risks associated with the consumption of allotment garden vegetables, the application of daily metal intake and health risk index was performed on the vegetables grown in the garden soil. Accordingly, values of daily metal intake were extremely low (ranging 0 to $20 \mu \mathrm{g} \mathrm{kg}^{-1}$ body weight day ${ }^{-1}$, data not shown) and this resulted in limited health risk index values. The health risk index was greatest in radish for $\mathrm{Cr}, \mathrm{Cu}$ and $\mathrm{Pb}$ (Table 2), reaching respectively $0.015,0.13$ and 0.45 in adults ( $70 \mathrm{~kg}$ body weight and $0.22 \mathrm{~kg} \mathrm{day}^{-1}$ daily plant consumption, Leclercq et al. 2009) and 0.032, 0.270 and 0.951 in children $\left(26 \mathrm{~kg}\right.$ body weight and $0.13 \mathrm{~kg}$ day $^{-1}$ daily plant consumption, Leclercq et al. 2009) (Table 2). The same index was not affected by the crop species in neither adults $(0.026)$ nor children (0.055) when Ni was considered (Table 2). The health risk index estimated on both adults and children resulted to be below the toxicity level of 1 (US-EPA IRIS 2006), although the index value associated with $\mathrm{Pb}$ was greatest in radish, confirming its associated health risks when grown in contaminated environments.

\section{Conclusions}

The experimental garden presented moderately high levels of $\mathrm{Cr}$, whereas $\mathrm{Cu}, \mathrm{Pb}$ and $\mathrm{Ni}$ were within ranges observed in both urban and rural vegetable gardens assessed in previous studies. Indeed, while $\mathrm{Cr}$ content in edible organs was lower than values observed in previous studies, $\mathrm{Ni}$ and $\mathrm{Cu}$ were higher than previous evidences. Furthermore, $\mathrm{Pb}$ concentration in edible radish roots resulted to be above risk thresholds indicated by the EU. Nonetheless, for all studied trace metals, daily metal intake and health risk index of plants grown on soil were below the threshold value for health risks. Among the studied plants, radish most accumulated toxic elements, which resulted in significantly greater risk from all other studied crops, reaching values close to toxicity for $\mathrm{Pb}$ when health risk index was associated with children consumption. All studied crops presented bioaccumulation factor values always below 1, although with the highest values for $\mathrm{Cr}, \mathrm{Cu}, \mathrm{Pb}$ and $\mathrm{Ni}$ in radish. The translocation factor of $\mathrm{Cu}$ from root to shoot was greater in leaves of sweet basil than that of $\mathrm{Pb}$ and $\mathrm{Ni}$ in kale, as compared to the translocation to fruits in tomato. Plants grown in peat in simplified soilless systems showed reduced content of $\mathrm{Cr}, \mathrm{Cu}, \mathrm{Pb}$ and $\mathrm{Ni}$ as compared to those grown in soil, due to differences in the growing media in terms of the concentration of the element and biochemical properties ( $\mathrm{pH}$ and $\mathrm{CaCO}_{3}$ ). Organic fertilization resulted in increased $\mathrm{Cr}$ and $\mathrm{Pb}$ and reduced $\mathrm{Cu}$ and $\mathrm{Ni}$ in the edible organs of some of the studied crops. According to the results of the present study, the adoption of soilless growing systems where plants are grown in peat may be a feasible strategy to cope with trace metal contamination risk in urban allotment garden. The absence of clear differences in trace metal accumulation as affected by either mineral or organic fertilizers, on the other hand, suggests that deeper studies should be conducted in order to define proper fertilization strategies in potentially polluted environments.

Acknowledgments The research was partially funded by the Erasmus+ project Urban Green Train (Urban Green Education for Enterprising Agricultural Innovation). English language was checked by Dr. Agata Pennisi Sacoor.

\section{References}

Agrawal M, Singh B, Rajput M, Marshall F, Bell JNB (2003) Effect of air pollution on peri-urban agriculture: a case study. Environ Pollut 126: 323-329. doi:10.1016/S0269-7491(03)00245-8

Ali MH, Al-Qahtani KM (2012) Assessment of some heavy metals in vegetables, cereals and fruits in Saudi Arabian markets. Egypt J Aquat Res 38:31-37. doi:10.1016/j.ejar.2012.08.002

Alloway BJ (2004) Contamination of soils in domestic gardens and allotments: a brief overview. Land Contam Reclam 12:179-187. doi:10.2462/09670513.658

Aylor DE (1972) Noise reduction by vegetation and ground. J Acoust Soc Am 51:197-205. doi:10.1121/1.1912830

Baker AJM, Brooks RR (1989) Terrestrials higher plants which hyperaccumulate metallic elements. A review of their distribution, ecology and phytochemistry. Biorecovery 1:81-126

Barthel S, Folke C, Colding J (2010) Social-ecological memory in urban gardens - retaining the capacity for management of ecosystem services. Glob Environ Chang 20:255-265. doi:10.1016/j. gloenvcha.2010.01.001

Breuste JH, Artmann M (2014) Allotment gardens contribute to urban ecosystem service: case study Salzburg, Austria. J Urban Plann Dev 141, A5014005. doi:10.1061/(ASCE)UP.1943-5444.0000291 
Caldeyro-Stajano M (2004) Simplified hydroponics as an appropriate technology to implement food security in urban agriculture. Pract Hydroponics Greenh 76:1-6

Christensen BT, Elsgaard L (2014) Comparing heavy metal contents in crops receiving mineral fertilisers and animal manure. Int Fertil Soc: Proc 761. http://fertiliser-society.org/proceedings/uk/Prc761.HTM. Accessed 2 July 2016

Chu LM, Wong MH (1987) Heavy metal contents of vegetable crops treated with refuse compost and sewage sludge. Plant Soil 103: 191-197. doi:10.1007/BF02370388

Clemens S, Ma JF (2016) Toxic heavy metal and metalloid accumulation in crop plants and foods. Annu Rev Plant Biol 67:12.1-12.24. doi:10.1146/annurev-arplant-043015-112301

Cluis C (2004) Junk-greedy greens: phytoremediation as a new option for soil decontamination. BioTech J 2:60-67

Cui YJ, Zhu YG, Zhai RH, Chen DY, Huang YZ, Qiu Y, Liang JZ (2004) Transfer of metals from soil to vegetables in an area near a smelter in Nanning, China. Environ Int 30:785-791. doi:10.1016/j. envint.2004.01.003

Davies ZG, Edmondson JL, Heinemeyer A, Leake JR, Gaston KJ (2011) Mapping an urban ecosystem service: quantifying above-ground carbon storage at a city-wide scale. J Appl Ecol 48:1125-1134. doi:10.1111/j.1365-2664.2011.02021.x

Douay F, Pelfrêne A, Planque J, Fourrier H, Richard A, Roussel H, Girondelot B (2013) Assessment of potential health risk for inhabitants living near a former lead smelter. Part 1: metal concentrations in soils, agricultural crops, and homegrown vegetables. Environ Monit Assess 185:3665-3680. doi:10.1007/s10661-012-2818-3

Drescher AW (2004) Food for the cities: urban agriculture in developing countries. Acta Hortic 643:227-231. doi:10.17660 /ActaHortic.2004.643.29

EU (2009) Commission Regulation (EU) No 420/2011 of 29 April 2011 amending Regulation (EC) No 1881/2006 setting maximum levels for certain contaminants in foodstuffs. http://eur-lex.europa. $\mathrm{eu} /$ legalcontent/EN/TXT/HTML/?uri=CELEX:32011R0420 $\&$ from $=\mathrm{EN}$. Accessed 5 March 2016

Fayiga AQ, Ma LQ (2006) Using phosphate rock to immobilize metals in soils and increase arsenic uptake in Pteris vittata. Sci Total Environ 359:17-25. doi:10.1016/j.scitotenv.2005.06.001

Gee GW, Bauder JW (1986) Particle-size analysis. In: Klute A (ed) Methods of soil analysis. Part 1. Physical and mineralogical methods. Am Soc Agron, Madison, pp 383-411

Izquierdo M, De Miguel E, Ortega MF, Mingot J (2015) Bioaccessibility of metals and human health risk assessment in community urban gardens. Chemosphere 135:312-318. doi:10.1016/j. chemosphere.2015.04.079

Jan FA, Ishaq M, Khan S, Ihsanullah I, Ahmad I, Shakirullah M (2010) A comparative study of human health risks via consumption of food crops grown on wastewater irrigated soil (Peshawar) and relatively clean water irrigated soil (lower Dir). J Hazard Mater 179:612-621. doi:10.1016/j.jhazmat.2010.03.047

Jean-Soro L, Le Guern C, Bechet B, Lebeau T, Ringeard MF (2015) Origin of trace elements in an urban garden in Nantes, France. J Soils Sediments 15:1802-1812. doi:10.1007/s11368-014-0952-y

Kabala C, Chodak T, Szerszen L, Karczewska A, Szopka K, Fratczak U (2009) Factors influencing the concentration of heavy metals in soils of allotment gardens in the city of Wroclaw, Poland. Fresenius Environ Bull 118:1118-1124

Kumpiene J, Lagerkvist A, Maurice C (2008) Stabilization of As, Cr, Cu, $\mathrm{Pb}$ and $\mathrm{Zn}$ in soil using amendments - a review. Waste Manag 28: 215-225. doi:10.1016/j.wasman.2006.12.012

Leclercq C, Arcella D, Piccinelli R, Sette S, Le Donne C, Turrini A (2009) The Italian national food consumption survey INRANSCAI 2005-2006: main results in terms of food consumption. Public Health Nutr 12:2504-2532. doi:10.1017 /S1368980009005035
Lin BB, Philpott SM, Jha S (2015) The future of urban agriculture and biodiversity-ecosystem services: challenges and next steps. Basic Appl Ecol 16:189-201. doi:10.1016/j.baae.2015.01.005

Liñero O, Cidad M, Carrero JA, Nguyen C, de Diego A (2015) Accumulation and translocation of essential and nonessential elements by tomato plants (Solanum lycopersicum) cultivated in open-air plots under organic or conventional farming techniques. J Agric Food Chem 63:9461-9470. doi:10.1021/acs.jafc.5b03878

Luo C, Liu C, Wang Y, Liu X, Li F, Zhang G, Li X (2011) Heavy metal contamination in soils and vegetables near an e-waste processing site, south China. J Hazard Mater 186:481-490. doi:10.1016/j. jhazmat.2010.11.024

Ma LQ, Komar KM, Tu C, Zhang W, Cai Y, Kenelly ED (2001) A fern that hyper accumulates arsenic. Nature 409:579-582. doi:10.1038 135054664

Massaquoi LD, Ma H, Liu XH, Han PY, Zuo SM, Hua ZX, Liu DW (2015) Heavy metal accumulation in soils, plants, and hair samples: an assessment of heavy metal exposure risks from the consumption of vegetables grown on soils previously irrigated with wastewater. Environ Sci Pollut Res 22:18456-18468. doi:10.1007/s11356-0155131-1

Orsini F, Kahane R, Nono-Womdim R, Gianquinto G (2013) Urban agriculture in the developing world: a review. Agron Sustain Dev 33: 695-720. doi:10.1007/s13593-013-0143-Z

Orsini F, Gasperi D, Marchetti L, Piovene C, Draghetti S, Ramazzotti S, Bazzocchi GG, Gianquinto G (2014) Exploring the production capacity of rooftop gardens (RTGs) in urban agriculture: the potential impact on food and nutrition security, biodiversity and other ecosystem services in the city of Bologna. Food Sec 6:781-792. doi:10.1007/s12571-014-0389-6

Phelan PE, Kaloush K, Miner M, Golden J, Phelan B, Silva H III, Taylor RA (2015) Urban heat island: mechanisms, implications, and possible remedies. Annu Rev Environ Resour 40:285-307. doi:10.1146 /annurev-environ-102014-021155

Rattan RK, Datta SP, Chhonkar PK, Suribabu K, Singh AK (2005) Longterm impact of irrigation with sewage effluents on heavy metal content in soils, crops and groundwater - a case study. Agric Ecosyst Environ 109:310-322. doi:10.1016/j.agee.2005.02.025

ARPA-RER Regione Emilia Romagna (2004) Relazione sullo stato dell'ambiente della regione Emilia Romagna

Rezvani M, Zaefarian F (2011) Bioaccumulation and translocation factors of cadmium and lead in 'Aeluropus littoralis'. Aust J Agric Eng 2:114

Rowell DL (2014) Soil science: methods and applications. Taylor and Francis, Routledge, London

Säumel I, Kotsyuk I, Hölscher M, Lenkereit C, Weber F, Kowarik I (2012) How healthy is urban horticulture in high traffic areas? Trace metal concentrations in vegetable crops from plantings within inner city neighbourhoods in Berlin, Germany. Environ Pollut 165: 124-132. doi:10.1016/j.envpol.2012.02.019

Singh A, Agrawal M, Marshall FM (2010) The role of organic vs. inorganic fertilizers in reducing phytoavailability of heavy metals in a wastewater-irrigated area. Ecol Eng 36:1733-1740. doi:10.1016/j. ecoleng.2010.07.021

Szolnoki Z, Farsang A, Puskas I (2013) Cumulative impacts of human activities on urban garden soils: origin and accumulation of metals. Environ Pollut 177:106-115. doi:10.1016/j.envpol.2013.02.007

Tiwari KK, Singh NK, Patel MP, Tiwari MR, Rai UN (2011) Metal contamination of soil and translocation in vegetables growing under industrial wastewater irrigated agricultural field of Vadodara, Gujarat, India. Ecotoxicol Environ Saf 74:1670-1677. doi:10.1016 /j.ecoenv.2011.04.029

Tixier P, de Bon H (2006) Urban horticulture. Cities farming for the future, urban agriculture for green and productive cities. RUAF Foundation, IDRC and IIRR. ETC.-Urban Agriculture, Leusden. http://www.ruaf.org/publications/cities-farming-future-urbanagriculture-green-and-productive-cities. Accessed 2 July 2016 
UM (2014) (Umweltinstitut München): Pestizide (Pesticides). URL: http://www.umweltinstitut.org/themen/landwirtschaft /pestizide/glyphosat/haus-und-kleingarten.html. Accessed 24 February 2016

US-EPA IRIS (2006) United States, environmental protection agency, integrated risk information system. http://www.epa.gov/iris/substS

Vittori Antisari L, Carbone S, Ferronato C, Simoni A, Vianello G (2012) Leaf washing as an assessment tool to characterize dry atmospheric deposition. Int J Environ Qual 9:37-50. doi:10.6092/issn.2281-4485/3737

Vittori Antisari L, Ventura F, Simoni A, Piana S, Rossi Pisa P, Vianello G (2013) Assessment of pollutants in wet and dry deposition in a suburban area around a waste-to-energy plants (WEP) in Northern Italy. J Environ Prot 4:16-25. doi:10.4236/jep.2013.45A003

Vittori Antisari L, Orsini F, Marchetti L, Vianello G, Gianquinto G (2015) Heavy metal accumulation in vegetables grown in urban gardens. Agron Sustain Dev 35:1139-1147. doi:10.1007/s13593-015-0308-Z

Voigt A, Leitao TE, Hursthouse AS, Jokinen A, Heller A, Latkowska M, Brito da Luz P, Christ Y, Bechet B, Kulvik M, Langemeyer J (2016) Lessons learned: indicators and good practice for an environmentally friendly urban garden. In: Bell S, Fox-Kamper R, Keshavarz N, Drilling M, Benson M, Voigt A, Caputo S (eds) Urban allotment gardens in Europe. Taylor and Francis, Routledge, London, pp.165-197

Warming M, Hansen MG, Holm PE, Magid J, Hansen TH, Trapp S (2015) Does intake of trace elements through urban gardening in
Copenhagen pose a risk to human health? Environ Pollut 202:1723. doi:10.1016/j.envpol.2015.03.011

Yoon J, Cao X, Zhou Q, Ma LQ (2006) Accumulation of Pb, Cu, and $\mathrm{Zn}$ in native plants growing on a contaminated Florida site. Sci Total Environ 368:456-464. doi:10.1016/j. scitotenv.2006.01.016

Zaccone C, Di Caterina R, Rotunno T, Quinto M (2010) Soil-farming system-food-health: effect of conventional and organic fertilizers on heavy metal $(\mathrm{Cd}, \mathrm{Cr}, \mathrm{Cu}, \mathrm{Ni}, \mathrm{Pb}, \mathrm{Zn})$ content in semolina samples. Soil Tillage Res 107:97-105. doi:10.1016/j.still.2010.02.004

Zeng F, Ali S, Zhang H, Ouyang Y, Qiu B, Wu F, Zhang G (2011) The influence of $\mathrm{pH}$ and organic matter content in paddy soil on heavy metal availability and their uptake by rice plants. Environ Pollut 159:84-91. doi:10.1016/j.envpol.2010.09.019

Zezza A, Tasciotti L (2010) Urban agriculture, poverty, and food security: empirical evidence from a sample of developing countries. Food Policy 35:265-273. doi:10.1016/j.foodpol.2010.04.007

Zhang WH, Cai Y, Tu C, Ma QL (2002) Arsenic speciation and distribution in an arsenic hyperaccumulating plant. Sci Total Environ 300: 167-177. doi:10.1016/S0048-9697(02)00165-1

Zhang B, Xie G, Zhang C, Zhang J (2012) The economic benefits of rainwater-runoff reduction by urban green spaces: a case study in Beijing, China. J Environ Manag 100:65-71. doi:10.1016/j. jenvman.2012.01.015 